\title{
Osmotic diarrhoea and skeletal muscle protein synthesis in vivo
}

\author{
H Ansell, J S Marway, A B Bonner, J R Salisbury, D C A Candy, V R Preedy
}

\begin{abstract}
The pathogenic nature of the wasting seen in diarrhoea is unknown. This study measured protein synthesis in an established model of diarrhoea using lactose for seven days. Comparisons were also made with data obtained from rats fed an identical diet in which lactose was replaced by isocaloric glucose ad libitum (that is, the control diet). To account for diarrhoea induced anorexia, a third group of rats were included, which were fed identical amounts of the control diet as the rats with diarrhoea inducing diet. Comparisons of the diarrhoea induced group with rats fed the control diet ad libitum showed that diarrhoea caused a significant reduction in body weights. Type I and type II muscles showed significant reductions in protein, RNA, and DNA contents, as well as a fall in the derived parameters, RNA
\end{abstract} DNA, protein/DNA, and RNA/protein. Fractional rates of protein synthesis $\left(\mathbf{k}_{\mathbf{s}}\right)$ were also reduced. However, synthesis rates of type I and II muscles relative to RNA ( $\left.\mathbf{k}_{\mathbf{R N A}}\right)$ were unchanged in these muscles in diarrhoea induced rats compared with ad libitum fed controls. In the jejunum there was an increase in the RNA/DNA ratio, and reductions in $k_{s}$ and $\mathbf{k}_{\mathrm{RNA}}$. Comparisons were also made between rats with diarrhoea and rats pair fed the control diet. There were no changes in total muscle protein, RNA or DNA contents. This suggests that an important feature of body wasting in diarrhoea is the element of anorexia, which induces severe metabolic changes. The comparison between rats with diarrhoea and the pair fed group showed that histological features of the plantaris were not overtly changed, though diarrhoea caused significant reductions in RNA/DNA, protein/DNA, $k_{s}$, and $k_{R N A}$. Similar changes were seen for the soleus; though the reduction in $\mathbf{k}_{\mathrm{s}}$ failed to attain statistical significance. In the jejunum a comparison of diarrhoea induced rats with pair fed controls, showed increases in the ratios of RNA/DNA and protein/DNA.

(Gut 1996; 38: 40-46)

Keywords: muscle, type I muscle, type II muscle, jejunum, protein synthesis.

Osmotic diarrhoea is a common consequence of small intestinal disease, for example, infections or toxins such as ethanol. ${ }^{1-3}$ In rotavirus induced diarrhoea there is shortening of villi with enterocyte loss and establishment of a relatively young cell population with monosaccharide and disaccharide malabsorption and reduced sodium potassium ATPase activity leading to faeces with low sodium concentrations. ${ }^{4-7}$ Diarrhoea can be life threatening in the malnourished and the very young and there is also an increased risk of infection. ${ }^{78}$ Diarrhoea also causes tissue wasting and enhanced nitrogen excretion as well as reduced rates of growth, ${ }^{69}$ which may be contributory mechanisms in the aetiology of impaired immune function. ${ }^{10}$ In addition, skeletal muscle is an important contributor to whole body protein metabolism, namely about $40 \%$ of tissue mass and about $25 \%$ of whole body synthesis. ${ }^{11}$ It is therefore possible that the perturbed nitrogen homoeostasis commonly seen in diarrhoea (reviewed by Booth ${ }^{6}$ ) may in part result from defects in skeletal muscle protein retention. However, the biochemical effects of diarrhoea on skeletal muscle biochemistry are generally unknown. The changes in growth and perturbed nitrogen excretion implicate a role for changed protein turnover, and thus compensatory adjustments in protein synthesis or degradation, or both. ${ }^{11}$ In this study we investigated the contribution of protein synthesis and studied different muscle types (type I and type II fibre predominant skeletal muscles and small intestine). Measurements were carried out in vivo using what is arguably the most reliable method for measuring protein synthesis in small laboratory animals, which effectively considers precursor pools. ${ }^{12} 13$ The diarrhoea was induced by a method that has also been described in this journal. ${ }^{7}$

\section{Methods}

\section{Treatment of animals}

Osmotic diarrhoea was induced in male Wistar rats 4 weeks of age (approximately $60 \mathrm{~g}$ body weight; Charles Rivers, Margate, Kent, England) with lactose. ${ }^{14}$ Table I gives the composition of the diet. The rats were housed in a humidified, temperature controlled environment on a $12 \mathrm{~h}$ light $/ 12 \mathrm{~h}$ dark cycle. The rats were put in wire bottomed cages to minimise coprophagy, and there was no bedding available as additional source of calories. While every effort was made to ensure rats received the correct amount of calories, the study design did not influence how the nutrients were metabolised. The groups were:

Group (1) rats were fed ad libitum on a nutritionally complete liquid diet. The diet was identical to that used for treating groups (2) 
TABLE I Feeding regimens

\begin{tabular}{|c|c|c|c|c|}
\hline & Content $(g)$ & Total kcal & Total kf & $\mathrm{kf} / \mathrm{ml}$ \\
\hline \multicolumn{5}{|c|}{ Control diet, fed ad libitum to group (1) or pair fed to group (3) } \\
\hline Water & $800 \cdot 0$ & 0.0 & 0.0 & 0.0 \\
\hline Vitafood & $121 \cdot 0$ & $533 \cdot 6$ & $2232 \cdot 6$ & $2 \cdot 401$ \\
\hline Glucose & $85 \cdot 0$ & $318 \cdot 8$ & 1333.7 & 1.434 \\
\hline Casein & $10 \cdot 0$ & $40 \cdot 0$ & $167 \cdot 4$ & $0 \cdot 18$ \\
\hline Orovite & $3 \cdot 8$ & $14 \cdot 3$ & $59 \cdot 6$ & $0 \cdot 064$ \\
\hline Total & $1019 \cdot 8$ & $906 \cdot 6$ & $3793 \cdot 3$ & $4 \cdot 079$ \\
\hline \multicolumn{5}{|c|}{ Lactose diet fed ad libitum to group (2) } \\
\hline Water & $800 \cdot 0$ & 0.0 & $0 \cdot 0$ & $0 \cdot 0$ \\
\hline Vitafood & $121 \cdot 0$ & $533 \cdot 6$ & $2232 \cdot 6$ & $2 \cdot 401$ \\
\hline Lactose & $85 \cdot 0$ & $318 \cdot 8$ & 1333.7 & 1.434 \\
\hline Casein & $10 \cdot 0$ & $40 \cdot 0$ & $167 \cdot 4$ & $0 \cdot 18$ \\
\hline Orovite & $3 \cdot 8$ & $14 \cdot 3$ & $59 \cdot 6$ & 0.064 \\
\hline Total & $1019 \cdot 8$ & $906 \cdot 7$ & 3793.3 & 4.079 \\
\hline
\end{tabular}

Calorific values were calculated assuming carbohydrate $=3.75$ $\mathrm{kcal} / \mathrm{g}$, protein $=4.0 \mathrm{kcal}$, fat $=9.0 \mathrm{kcal} / \mathrm{g}$, and $4.18 \mathrm{~kJ}$ was assumed to be equal to $1 \mathrm{kcal}$. The total measured volume of both diets was $930 \mathrm{ml}$. The groups were as follows: (1) control, ad libitum; (2) diarrhoea; (3) control, pair fed.

Orovite contains sucrose, hence its low contribution to overall caloric intake.

and (3), albeit differences in the proportion of calories provided by lactose in group (2).

Group (2) rats were fed ad libitum the liquid diet containing lactose. The treatment regimen induced diarrhoea. The presence of diarrhoea was distinctly conspicuous; the floors of the cages were soiled and the stools liquified. The anal areas were wet and the fur around the anus of these rats was damp. These effects were not seen in control rats.

Group (3) rats were subjected to control feeding and were given identical amounts of the diet consumed by group (2) though lactose was replaced by isocaloric glucose (that is, a pair feeding regimen).

\section{Method of pair feeding}

Before the study began all rats were ranked in order of body weight and divided into the above groups. The method of pair feeding entailed measuring the volume of liquid diet consumed by each rat in group (2) over a 24 hour period. Using this figure an identical amount of control liquid diet was given to the counter matched rat in group (3). The amount of diet consumed by the rats in group (2) were recorded daily and the pair feeding principle applied to rats in group (3) on a daily basis.

The model of inducing diarrhoea has been described previously ${ }^{14}$ as well as in this journal. ${ }^{7}$ The basis of the model is the limited ability of intestinal tissue to metabolise lactose and indeed some other sugars. For example diarrhoea can also be induced with fructose. ${ }^{15}$ The impaired ability of the small intestine to digest the lactose raises intralumenal osmolarity. To compensate for this, water traverses into the lumen of the intestine, to facilitate an equilibrium of osmolarity in the intracellular and extracellular partitions. The increased water content in the lumen causes watery stools. However, the physiological processes are not entirely this simple as the lactose will be subjected to bacterial fermentation giving rise to short chain fatty acids, methane, hydrogen, carbon dioxide, and lactate. ${ }^{16}$ The histological changes in the small bowel mucosa are similar to those seen in young subjects with persistent diarrhoea or gastroenteritis. An exceptionally important feature of our study, however, is the inclusion of a group of pair fed rats (group (3)), to take account of the anorexia or reduced dietary intake. Sadly, numerous studies on the pathophysiology of infectious and non-infectious diarrhoea have failed to consider this aspect and this study is novel in this respect.

\section{Measurement of protein synthesis}

After one week of treatment, rates of protein synthesis were measured with a flooding dose of L- $\left[4^{3} \mathrm{H}\right]$ phenylalanine (injected at a dose of $150 \mathrm{mmol} / \mathrm{l}, 1 \mathrm{ml} / 100 \mathrm{~g}$ body weight, intravenously) to label the intramuscular and extracellular free amino acid pools. ${ }^{17}$ After death the hind legs were stripped free of skin and quickly placed in an ice and water slurry. The whole small intestinal length was also dissected, rapidly cooled in ice cold saline $(0 \cdot 15$ $\mathrm{mol} / \mathrm{l} \mathrm{NaCl}$ ), and its length measured, by suspending one end with a weight (3.2 gram). Whole jejunal segments $(15 \mathrm{~cm}$ taken from the centre of the small intestine) were then rapidly dissected out and flushed with ice cold saline, blotted, weighed, and frozen in liquid nitrogen. The soleus (type I fibre predominant) and plantaris (type II fibre predominant) muscles were dissected, blotted, weighed, and plunged into liquid nitrogen. The time between injection of the isotope and immersion of the legs in the ice water slurry, or intestine into saline, was accurately timed (that is, about 11 and 12 minutes for the muscle and intestine). All tissues were stored at a temperature of $-70^{\circ} \mathrm{C}$ until processing.

All ensuing steps of tissue processing were kept between $0-4^{\circ} \mathrm{C}$. Tissues were homogenised with an ultrasonic tissue homogeniser (Polytron, Kinematica, Philip Harris Scientific, London, UK) and processed for determination of protein bound and free phenylalanine specific radioactivities. ${ }^{17}$ Fractional rates of protein synthesis (defined as the percentage of tissue protein renewed each day, that is, \%/day) were calculated from the formula: $k_{s}=\left(S_{b} \times 100\right) /\left(S_{i} \times t\right)$; where ' $S_{b}$ ' is the specific radioactivity of phenylalanine in tissue protein $(\mathrm{dpm} / \mathrm{nmol})$; ' $\mathrm{S}_{\mathrm{i}}$ ' is the specific radioactivity of free phenylalanine in acid soluble fractions of muscle or intestinal homogenates $(\mathrm{dpm} / \mathrm{nmol})$; ' $\mathrm{t}$ ' is the period between injection of the isotope and immersion of the legs into the ice water mixture or intestine in ice cold saline (in days). Both $S_{i}$ and $S_{b}$ were assayed according to the method of Garlick et al. ${ }^{17}$ The formula assumes that the free amino acid at the site of protein synthesis (the amino acyl tRNA) was represented by the free amino acid in the intracellular pools. Other assays were routine procedures for protein, ${ }^{18} \mathrm{RNA},{ }^{19} 20$ and DNA. ${ }^{21}$

\section{Methodological considerations}

In these studies we were mindful of the fact that a large number of the metabolic studies on muscle are carried out in isolated systems, or have used inappropriate methodology 
to measure protein synthesis. We were also mindful of the fact that any in vitro phenomena must be transposed to the intact mammalian system. These facets have recently been the subject of much controversy and have been reviewed by Garlick et $a l,{ }^{12}$ Rennie et $a l,{ }^{13}$ and Preedy et al. ${ }^{22}$ In this study, we carried out protein synthesis studies in young growing rats using what is arguably the most reliable technique for measuring protein synthesis in laboratory animals in vivo to date. The flooding dose technique effectively considers that any reliable protein synthesis data have to measure the specific radioactivity of the precursor at the site of protein synthesis. ${ }^{11} 12$ Theoretically this is the aminoacyl tRNA $\left(S_{t R N A}\right)$. However, the practicalities of amino-acyl tRNA measurements are such that their determinations are difficult to facilitate on a routine basis. In the flooding dose technique, the large amount of phenylalanine floods all endogenous free amino acid pools, such that all tissue free phenylalanine specific radioactivities $\left(S_{i}\right)$ in the different pools attain similar values. ${ }^{12} 17$ Free phenylalanine specific radioactivities are also similar to the values in the extracellular pools $\left(\mathrm{S}_{\mathrm{p}}\right){ }^{17}$ Thus $S_{\mathrm{tRNA}} \equiv \mathrm{S}_{\mathrm{i}} \equiv \mathrm{S}_{\mathrm{p}} \cdot{ }^{17}$ Measurements of acid supernatants of tissue homogenates are therefore sufficient for extracting free radiolabelled phenylalanine for subsequently calculating rates of protein synthesis. ${ }^{17}$ However, we also measured $k_{s}$ by substituting $S_{i}$ with $S_{p}$ in the formula for calculating synthesis rates (effectively considering the possibility the $S_{t R N A}$ values were better represented by the free amino acid in extracellular pools) and identical qualitative conclusions were obtained (not shown for brevity). It is possible that differences in $k_{s}$ and $k_{R N A}$ resulted from changes in precursor enrichment - that is, changed $S_{i}$ or $S_{p}$ values. In the type I and type II muscles, however, $S_{i}$ values were not significantly different in any experimental group. Similarly $S_{p}$ was only changed by the diarrhoea treatment regimen by $5 \%$ (not shown for brevity) and therefore cannot be responsible for the differences in $k_{s}$ or $\mathrm{k}_{\mathrm{RNA}}$.

\section{Histological assessment}

Tissue samples were placed on cork discs, secured with cryostable adhesive, snap frozen in isopentane (maintained at $-196^{\circ} \mathrm{C}$ for one minute), and stored at $-70^{\circ} \mathrm{C}$. Serial sections of $10 \mu \mathrm{m}$ thickness were cut and stained with haematoxylin and eosin and for myosin-ATPase at $\mathrm{pH} 9 \cdot 5^{23-25}$ to allow for fibre typing. The haematoxylin and eosin and ATPase sections were examined qualitatively (having coded test and control samples so that assessment was made 'blind') then histomorphometric measurements of skeletal muscle fibre diameters were made by placing the ATPase sections on the stage of a Zeiss IIIRS microscope (Carl Zeiss (Oberkocken), Welwyn Garden City, Herts, UK) to which was attached an Ikegami CCD camera
(Ikegami Electronics (Europe) $\mathrm{GmbH}$ UK Branch, Chertsey, Surrey, UK). Captured images were digitised and fed to a Colourmorph interactive image analysis system (Perceptive Instruments, Haverhill, Suffolk, UK) running on an Elonex 386S microcomputer with a NEC 'Multisync plus' monitor at a resolution of $640 \times 480$ pixels. The equipment used enabled the optical image of the histological section examined down the microscope to be visualised on the monitor screen. A mouse was used to interactively demarcate the lesser fibre diameter of each fibre.

\section{Statistics}

Data are presented as the mean (SEM) of five to six findings in each group. Differences between means were assessed using an analysis of variance, followed by Student's $t$ test incorporating the pooled estimate of variance. NS, not significant; $p>0.05$.

\section{Results}

Body and tissue weights and gut lengths

The data in Table II show that in comparison to the ad libitum glucose fed rats (group (1)), group (2) rats showed a significant reduction in final body weights $(-14 \%, \mathrm{p}<0.001)$ and concomitant reductions in the weights of the soleus and plantaris (by 22 and 29\% respectively). However, there was no significant change in jejunal weights. The mean lengths of the jejunum in groups (1), (2), and (3) were $99 \cdot 1(2 \cdot 8), 111.2(2 \cdot 5), 94.9(2.5) \mathrm{cm}$ respectively. Compared with the rats in group

TABLE II Body and tissue weights in experimental diarrhoea

\begin{tabular}{|c|c|c|c|}
\hline & & $\begin{array}{l}\% \text { Change } \\
\text { from } \\
\text { group (1) }\end{array}$ & p Value \\
\hline \multicolumn{4}{|c|}{ Body weights $(g)$} \\
\hline (1) Control, ad libitum & $59 \cdot 3(1 \cdot 1)$ & & \\
\hline (2) Diarrhoea & $59.7(1.4)$ & +1 & NS \\
\hline $\begin{array}{l}\text { (3) Control, pair fed } \\
\text { (2) versus (3), }+1 \%, N\end{array}$ & $s^{59 \cdot 4(1 \cdot 2)}$ & 0 & NS \\
\hline Final & & & \\
\hline (1) Control, ad libitum & $\begin{array}{l}92(2) \\
79(1)\end{array}$ & -14 & $<0.001$ \\
\hline $\begin{array}{l}\text { (3) Control, pair fed } \\
\text { (2) versus (3), }+6 \%, p\end{array}$ & $\begin{array}{l}74(2) \\
<0.05\end{array}$ & -20 & $<0.001$ \\
\hline \multicolumn{4}{|c|}{ Tissue wet weights (mg) } \\
\hline Soleus (type I) & 74 (3) & & \\
\hline (2) Diarrhoea & $58(3)$ & -22 & $<0.001$ \\
\hline $\begin{array}{l}\text { (3) Control, pair fed } \\
\text { (2) versus (3), }-5 \%, \mathrm{~N} \\
\text { Plantaris (type II) }\end{array}$ & $s^{61(3)}$ & -18 & $<0.005$ \\
\hline (1) Control, ad libitum & $136(4)$ & & \\
\hline (2) Diarrhoea & $96(4)$ & -29 & $<0.001$ \\
\hline $\begin{array}{l}\text { (3) Control, pair fed } \\
\text { (2) versus (3), -3\%, N }\end{array}$ & $100(5)$ & -26 & $<0.001$ \\
\hline Fejunum & & & \\
\hline $\begin{array}{l}\text { (1) Control, ad libitum } \\
\text { (2) Diarrhoea }\end{array}$ & $\begin{array}{l}769(25) \\
716(40)\end{array}$ & -7 & $\mathbf{N}$ \\
\hline (3) Control, pair fed & $680(29)$ & -12 & $<0.05$ \\
\hline
\end{tabular}

Male Wistar rats were either fed the glucose or lactose

containing diet ad libitum (groups (1) and (2), respectively) To compensate for the anorexia, rats of group (3) were pair fed. Rats were killed after one week and pairs of soleus and plantaris muscles and $15 \mathrm{~cm}$ of jejunum taken for analysis. Differences between groups (2) and (3) are shown under each set of data and expressed as a percentage of group (3). Data shown as mean (SEM). 
TABLE III Protein RNA and DNA contents in experimental diarrhoea

\begin{tabular}{|c|c|c|c|}
\hline & & $\begin{array}{l}\% \text { Change } \\
\text { from } \\
\text { group (1) }\end{array}$ & $p$ Value \\
\hline \multicolumn{4}{|c|}{ Tissue protein content $(\mathrm{mg})$} \\
\hline \multicolumn{4}{|c|}{$\begin{array}{l}\text { Soleus (type I) } \\
\text { (1) Control, ad libitum } 13 \text { (1) }\end{array}$} \\
\hline (2) Diarrhoea & 9 (1) & -31 & $<0.001$ \\
\hline (3) Control, pair fed & $10(1)$ & -23 & $<0.025$ \\
\hline \multicolumn{4}{|c|}{$\begin{array}{l}\text { (2) versus (3), }-11 \%, \text { NS } \\
\text { Plantaris (type II) }\end{array}$} \\
\hline (1) Control, ad libitum & $24(1)$ & & \\
\hline (2) Diarrhoea & $14(2)$ & -42 & $<0.001$ \\
\hline (3) Control, pair fed & $15(1)$ & -38 & $<0.001$ \\
\hline \multirow{2}{*}{\multicolumn{4}{|c|}{$\begin{array}{l}\text { (2) versus (3), }-7 \% \text {, NS } \\
\text { fejunum }\end{array}$}} \\
\hline & & & \\
\hline (2) Diarrhoea & $33(2)$ & -6 & NS \\
\hline $\begin{array}{l}\text { (3) Control, pair fed } \\
\text { (2) versus (3), }+6 \%, \mathrm{~N}\end{array}$ & $\begin{array}{l}31(1) \\
\text { vS }\end{array}$ & -11 & $<0.05$ \\
\hline \multicolumn{4}{|c|}{ Tissue RNA content $(\mathrm{mg})$} \\
\hline $\begin{array}{l}\text { Soleus (type I) } \\
\text { (1) Control, ad libitum }\end{array}$ & $0.16(0.01)$ & & \\
\hline (2) Diarrhoea & $0.10(0.01)$ & -38 & $<0.001$ \\
\hline (3) Control, pair fed & $0.11(0.01)$ & -31 & $<0.001$ \\
\hline \multicolumn{4}{|l|}{$\begin{array}{l}\text { (2) versus (3), } \\
\text { Plantaris (type II) }\end{array}$} \\
\hline (1) Control, ad libitum & $0.25(0.01)$ & & \\
\hline (2) Diarrhoea & $0.13(0.02)$ & -48 & $<0.001$ \\
\hline (3) Control, pair fed & $0 \cdot 15(0.01)$ & -40 & $<0.001$ \\
\hline \multirow{2}{*}{\multicolumn{4}{|c|}{ fejunum }} \\
\hline (1) Control, ad libitum & $7 \cdot 3(0 \cdot 2)$ & & \\
\hline $\begin{array}{l}\text { (2) Diarrhoea } \\
\text { (3) Control, pair fed } \\
\text { (2) versus (3), }+12 \% \text {, }\end{array}$ & $\begin{array}{l}7.4(0.3) \\
6.5(0.3) \\
\text { NS }\end{array}$ & $\begin{array}{l}+1 \\
-11\end{array}$ & $\begin{array}{l}\text { NS } \\
\text { NS }\end{array}$ \\
\hline \multicolumn{4}{|c|}{ Tissue DNA content (mg) } \\
\hline \multicolumn{4}{|c|}{$\begin{array}{l}\text { Plantaris (type II) } \\
\text { (1) Control, ad libitum } \\
0.49(0.02)\end{array}$} \\
\hline (2) Diarrhoea & $0.32(0.03)$ & -35 & $<0.001$ \\
\hline (3) Control, pair fed & $0.31(0.01)$ & -37 & $<0.001$ \\
\hline \multirow{2}{*}{\multicolumn{4}{|c|}{ Gejunum }} \\
\hline (1) Control, ad libitum & $2.41(0.07)$ & & \\
\hline (2) Diarrhoea & $2.19(0.13)$ & 0 & y \\
\hline $\begin{array}{l}\text { (3) Control, pair fed } \\
\text { (2) versus (3), -2\%, N }\end{array}$ & $\mathrm{NS}^{2 \cdot 23(0 \cdot 10)}$ & -7 & NS \\
\hline
\end{tabular}

For experimental details see methods section and legend to Table II. There was insufficient sample for soleus DNA measurement. Data shown as mean (SEM).

(1) the length of the gut in rats of group (2) achieved significance $\mathrm{p}<0.001$.

\section{Biochemical findings: comparison of group (1) and (2)}

Table III shows that protein, RNA, and DNA contents were reduced in the soleus and plantaris of rats in group (2) when compared with ad libitum fed rats in group (1); (reductions of between $31-48 \%$, $\mathrm{p}<0.001)$. Derived parameters (Table IV) were also changed in group (2) compared with group (1): in the soleus and plantaris this included the $\mathrm{RNA} /$ protein ratio $(-16 \%$ and $-10 \%, p<0.005$ and $p<0.05$, respectively). The plantaris RNA/DNA and protein/DNA were also reduced by $23 \%$ and $12 \%$ respectively $(\mathrm{p}<0.001$ and $\mathrm{p}<0.025$, respectively). In the jejunum, there was a small increase in the RNA/DNA ratio $(+10 \%, \mathrm{p}<0.05$, see Table IV). There was insufficient material for determination of DNA in the soleus.

Rats in group (2) had lower rates of soleus and plantaris muscle protein synthesis (by $16-17 \%, \mathrm{p}<0.025$ in both instances, see Table $\mathrm{V})$ when compared with rats in group (1). This was not reflected by a reduced translation index $\left(k_{R N A}\right)$ in the soleus and plantaris suggesting that part of the change in protein synthesis in the rats resulted from transcription - that is, reductions in total tissue RNA. A considerable reduction in $\mathrm{k}_{\mathrm{RNA}}$ was seen in the jejunum $(-26 \%, \mathrm{p}<0.025)$.

Biochemical findings: comparison of group (2) and (3)

A comparison of group (2) and (3) showed a significant reduction in the following variables: plantaris RNA/DNA $(-12 \%, \mathrm{p}<0.01$, cell size (protein/DNA ratio, $-11 \%, \mathrm{p}<0.05), \mathrm{k}_{\mathrm{s}}$ $(-19 \%, \mathrm{p}<0.025), \mathrm{k}_{\mathrm{RNA}}(-23 \%, \mathrm{p}<0.01)$. Similar qualitative changes were seen for the soleus, though many of the variables failed to attain statistical significance, except the soleus $\mathrm{k}_{\mathrm{RNA}}(-20 \%, \mathrm{p}<0.005)$. In the jejunum the following differences were seen when comparing groups (2) and (3): RNA/DNA (+13\%, $\mathrm{p}<0.005)$ and protein/DNA $(+7 \%, \mathrm{p}<0.05)$.

A comparison of groups (1) and (3) showed that $k_{s}$ values were reduced in jejunum but not in soleus or plantaris. The reason for this differential sensitivity is not known.

Relative sensitivity of type I and II muscles The type II fibre predominant plantaris was more sensitive compared with the type I fibre predominant soleus and this was also confirmed by inspecting soleus/plantaris ratios - that is, type I/type II ratios for tissue weights, protein contents, and RNA contents for group (1) were $0.55(0.02), 0.52(0.03)$, and $0.63(0.05)$,

TABLE IV Derived parameters

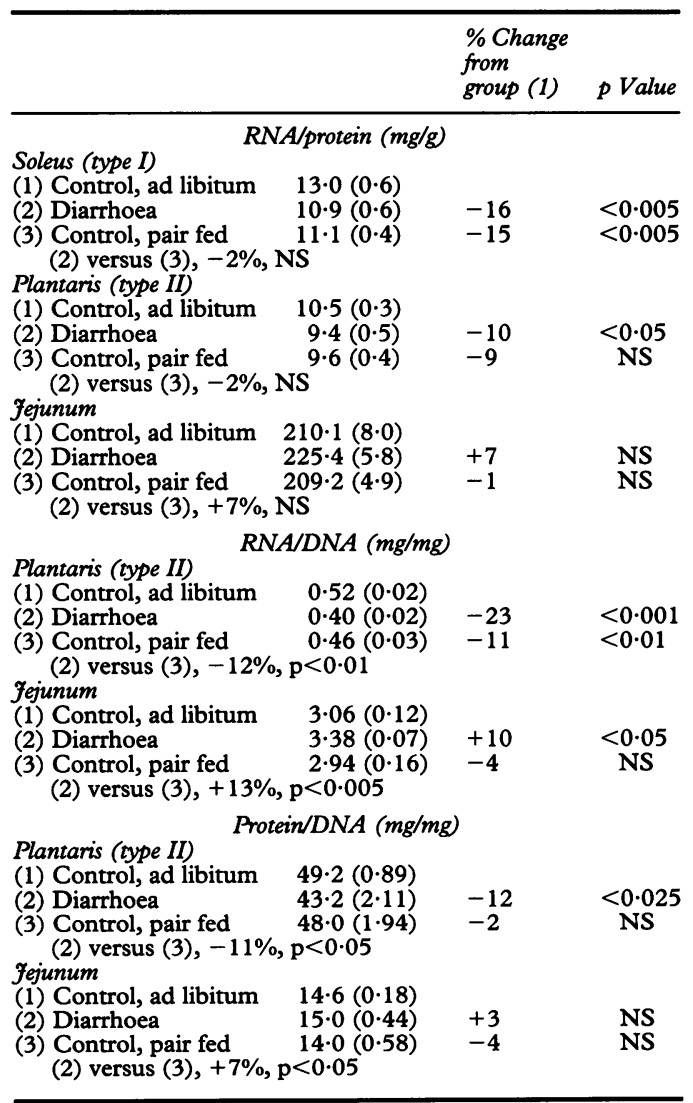

The RNA/DNA ratio value is equivalent to the amount of synthetic material per cell, protein/DNA represents cell size, and RNA/protein represents synthetic capacity. For other details see method section and legend to Table II. Data shown as mean (SEM). 


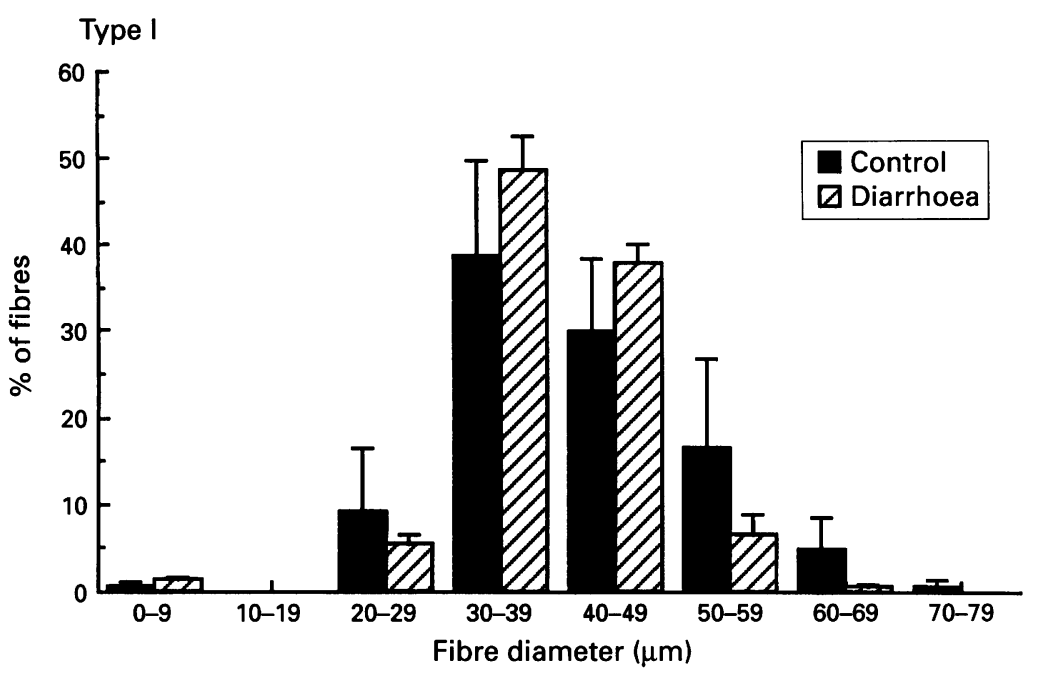

Type II

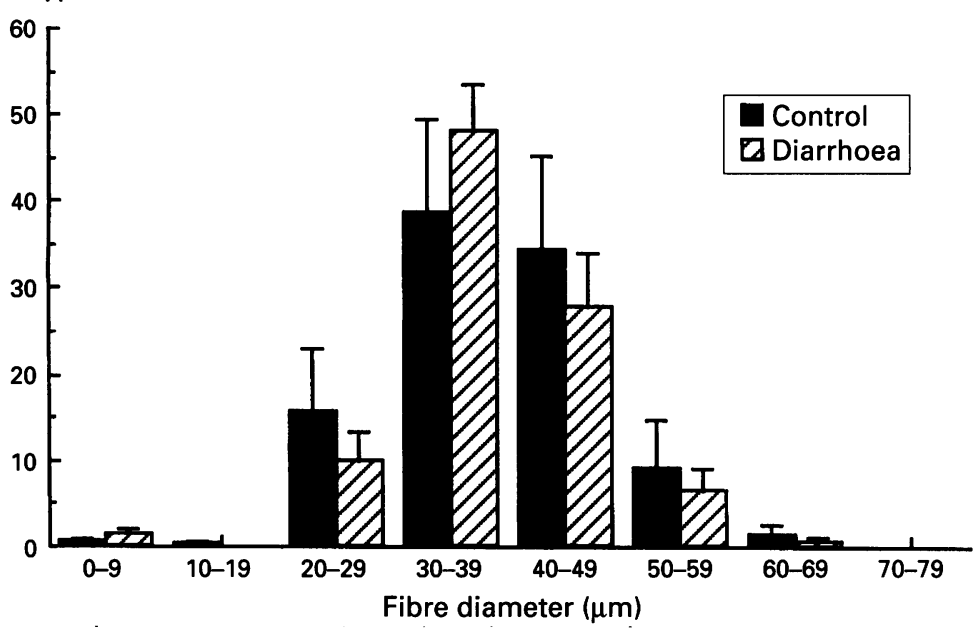

Fibre diameter distribution in plantaris muscles from diarrhoea and control, pair fed rats. Plantaris muscles from rats in groups (2) and (3) (diarrhoea and control, pair fed rats, respectively) were subjected to quantitative histomorphometry to measure the diameters of type I and type II fibres. The frequency distribution of lesser fibre diameters in groups (2) and (3) were not significantly different for any of the ranges. This generally reaffirms the quantitative compositional analysis of plantaris muscles from groups (2) and (3). A detailed histological description of the qualitative features of the plantaris muscles in these two groups is also given in the Results section. It is necessary to point out that a comparison of compositional parameters in plantaris muscles from groups (1) and (2) (control, ad libitum and control, pair fed rats, respectively) did indeed show considerable differences, but these changes were largely as a result of the anorexia.

respectively. In the rats with diarrhoea (group (2)) the following type I/type II ratios were obtained for weight: $0.61(0.03) \quad(p<0.025)$; protein content $0.71 \quad(0.09) \quad(\mathrm{p}<0.01)$, and RNA content $0.84(0.14)(\mathrm{p}<0.025)$.

\section{Histological examination}

Because of the practical constraints of limited resources we were unable to compare groups (1) and (2). Histological examinations, however, were confined to a comparison between groups (2) and (3). The light microscopy of the skeletal muscle samples showed no qualitative differences between lactose fed rats and pair fed control rats. Specifically, there was no abnormality of muscle fibre sarcoplasm and the mosaic of fibre types seemed normal for the type of muscle. There was no evidence of inflammation or necrosis or excess of fibrous or adipose tissue. Histomorphometric analysis of ATPase stained sections gave the frequency distribution of lesser fibre diameters shown in
TABLE V Fractional rates of protein synthesis

\begin{tabular}{|c|c|c|c|}
\hline & & $\begin{array}{l}\% \text { Change } \\
\text { from } \\
\text { group (1) }\end{array}$ & p Value \\
\hline \multicolumn{4}{|c|}{$\begin{array}{l}\text { Rates of protein synthesis in diarrhoea }\left(k_{\mathrm{s}} ; \% / \text { day }\right) \\
\text { Soleus (tupe I ) }\end{array}$} \\
\hline \multicolumn{2}{|c|}{$\begin{array}{l}\text { Soleus (type I) } \\
\text { (1) Control, ad libitum } \\
15 \cdot 1(1 \cdot 1)\end{array}$} & & \\
\hline (2) Diarrhoea & $12 \cdot 5(0 \cdot 7)$ & -17 & $<0.025$ \\
\hline $\begin{array}{l}\text { (3) Control, pair fed } \\
\text { (2) versus (3), }-17 \% \text {, }\end{array}$ & $\begin{array}{ll}14 \cdot 6(0 \cdot 9) \\
\text { NS }\end{array}$ & & NS \\
\hline \multicolumn{4}{|l|}{ Plantaris (type II) } \\
\hline (1) Control, ad libitum & $14 \cdot 1(0 \cdot 8)$ & & \\
\hline (2) Diarrhoea & $11.9(0.9)$ & -16 & $<0.025$ \\
\hline (3) Control, pair fed & $14 \cdot 2(0 \cdot 5)$ & +1 & NS \\
\hline \multicolumn{4}{|c|}{$\begin{array}{l}\text { (2) versus (3), }-19 \%, \mathrm{p}<0.025 \\
\text { fejunum }\end{array}$} \\
\hline (1) Control, ad libitum & $164 \cdot 4(29 \cdot 1)$ & & \\
\hline $\begin{array}{l}\text { (2) Diarrhoea } \\
\text { (3) Control, pair fed }\end{array}$ & $128 \cdot 9(8 \cdot 2)$ & $\begin{array}{l}-22 \\
-28\end{array}$ & $<0.05$ \\
\hline $\begin{array}{l}\text { (3) Control, pair fed } \\
\text { (2) versus (3), }+8 \%, N\end{array}$ & $117 \cdot 9(7 \cdot 0)$ & & $<0.023$ \\
\hline \multicolumn{4}{|c|}{$\begin{array}{l}R N A \text { activities ( } k_{\mathrm{RNA}} ; m g \text { protein/day/mg RNA) } \\
\text { Soleus (type I) }\end{array}$} \\
\hline (1) Control, ad libitum & $11 \cdot 2(0 \cdot 6)$ & & \\
\hline (2) Diarrhoea & $10 \cdot 8(0.5)$ & -4 & NS \\
\hline (3) Control, pair fed & $13 \cdot 0(0 \cdot 8)$ & +16 & $<0.025$ \\
\hline \multicolumn{4}{|c|}{$\begin{array}{l}\text { (2) versus (3), }-20 \%, \mathrm{NS} \\
\text { Plantaris (type II) }\end{array}$} \\
\hline (1) Control, ad libitum & $13 \cdot 4(0 \cdot 6)$ & & \\
\hline (2) Diarrhoea & $12 \cdot 4(0 \cdot 8)$ & -7 & NS \\
\hline $\begin{array}{l}\text { (3) Control, pair fed } \\
\text { (2) versus (3), }-23 \% \text {, }\end{array}$ & $\begin{array}{l}15 \cdot 2(0 \cdot 6) \\
p<0 \cdot 01\end{array}$ & +13 & $<0.05$ \\
\hline \multicolumn{4}{|l|}{ fejunum } \\
\hline (1) Control, ad libitum & $7 \cdot 7(1 \cdot 2)$ & & \\
\hline (2) Diarrhoea & $5 \cdot 7(0 \cdot 4)$ & -26 & $<0.025$ \\
\hline $\begin{array}{l}\text { (3) Control, pair fed } \\
\text { (2) versus (3), }-5 \%, \mathrm{~N}\end{array}$ & $5 \cdot 6(0 \cdot 2)$ & - & 025 \\
\hline
\end{tabular}

For details see methods section and legend to Table II. Data shown as mean (SEM).

the Figure. These analyses showed no significant change in muscle fibre diameters in the treated group from the pair fed group. Effectively, the quantitative morphometry confirm the biochemical findings showing that a substantial component of the biological changes in muscles during diarrhoea was caused by the anorexia.

\section{Discussion}

Infectious diarrhoea is a common cause of secondary lactose intolerance ${ }^{26}$ and repeated episodes lead to reduced rates of growth and increased mortality and morbidity. ${ }^{6}$ However, the biochemical mechanisms for changed growth rates remain obscure. The objective of this study was to find out (a) if osmotic diarrhoea in itself was inducing metabolic changes in muscle and (b) the mechanisms responsible for any changes in muscle protein content. With regard to (b), the concept of protein turnover implicates changes in tissue protein mass as resulting from changes in protein synthesis or protein degradation, or both. ${ }^{11}$ Although we did not measure the contribution of degradative pathways (because there are no reliable methods for determining this process in muscle in vivo ${ }^{27}$ ), we considered the problem by measuring rates of protein synthesis with the flooding dose technique and quantifying muscle RNA to show whether transcription was also modulated by diarrhoea. Two important points emerged from the results, the first was that diarrhoeal processes lead to metabolic changes in a tissue system far removed from the primary site of insult, namely skeletal muscle. These included loss of muscle weights, protein, RNA, and DNA contents, and reduced rates of synthesis. Secondly, reduc- 
tions in protein synthesis still occur when controlled feeding has been considered. However, when paired feeding had been taken into consideration (comparison of groups 2 and 3 ) the compositional changes were moderate. This was confirmed by the histological examinations.

Other studies have similarly shown body weight reductions in diarrhoea caused by cathartic agents such as magnesium citrate and phenolphthalein ${ }^{28}$ or lactose. ${ }^{14}$ In our model, concomitant changes included reductions in muscle weights and the amount of muscle protein and RNA. Diarrhoea induced significant reductions in muscle tissue protein synthesis. These changes occurred in the absence of infection, and histologically, the muscles from control and treated rats seemed normal. Also, the type II fibre predominant plantaris was more sensitive compared with the type I fibre predominant soleus and this was also confirmed by inspecting soleus/plantaris ratios.

Although our study was based on the experimental technique described by Nunez et $a l,{ }^{14}$ we included another set of rats (group (3)), which were subjected to controlled feeding (analogous to pair feeding). Thus, our data showed that reductions in protein synthesis occurred even when diarrhoea induced rats (group (2)) were compared with either pair fed controls or rats fed the liquid diet ad libitum. Group (3) rats were given glucose instead of lactose, but the amount of diet they received was identical to that of the anorexic animals in group (2). Therefore group (3) rats were deficient in calories when compared with group (1) rats fed ad libitum, hence it is difficult to postulate a mechanism how muscle protein synthesis $\left(k_{s}\right)$ in group (3) was comparable with group (1). Consideration should be given to the fact that degradation may also have been involved in mediating the changes in protein content. Alternatively, the endocrine status may have had an influence on $\mathrm{k}_{\mathrm{s}}$. Though a more important influence is the prevailing nutritional state of the rat.

Effectively, rats in group (3) were in a re-fed state while rats in groups (1) and (2) were postabsorptive at the time of synthesis measurement. Problems inherent in interpreting data in muscle from pair feeding regimens have been reviewed previously. ${ }^{29}$ Though one could argue that acute transitions in nutritional status influenced $\mathrm{k}_{\mathrm{s}}$ values, comparison of data clearly shows that the RNA composition, effectively an indicator of the protein synthetic potential, was reduced in plantaris muscles of groups (2) and (3) in comparison with group (1). Indeed the RNA/DNA ratio in plantaris muscle was $0.40(0.02)$ and $0.46(0.03)$ $(\mathrm{p}<0.01)$ in groups (2) and (3), respectively, clearly showing that protein synthetic potential was reduced.

Nunez et al ${ }^{14}$ reported that the lower bowel showed signs of inflammation and Bueno et al ${ }^{7}$ have shown that when diarrhoeal episodes have abated, there was still loss of enterocyte microvillar surface, lymphocyte infiltration, and abnormal mitochondria. The more insidious changes in the model must be considered: endotoxaemia may have occurred, or the diarrhoea may have induced perturbations in permeability, facilitating the ingress of toxins. ${ }^{30}$ It would not be inconceivable for the malabsorption of one or more micronutrients or electrolyte abnormalities to be responsible for the reduced protein synthesis in group (2).

In conclusion, the results showed loss of skeletal muscle protein caused by osmotic diarrhoea induced by lactose. As we were able to study the response in pair fed animals the contribution of anorexia was controlled. The model provides a suitable means of further examining the superimposition of other metabolic processes, such as endotoxaemia.

We are extremely grateful for the expert assistance of Vinood Patel. We are also grateful to Professor Timothy J Peters for encouragement and The University of London for financial support.

1 Turnburg LA. Clinical research reviews: diarrhoea new insights. Vol 1. 1-9. Marlow, UK: Janssen Pharmaceuticals Ltd, 1981.

2 Khoshoo V, Bhan MK. Associated factors of protracted diarrhoea. Indian Pediatr 1990; 27: 559-69.

3 Collins J, Candy DCA, Spencer AJ, Osborne MP, Stephen J. Disaccharide activities in small intestine of rotavirusinfected suckling mice. A histochemical study. $₹$ Paediatr Gastroenterol Nutr 1990; 11: 395-403.

4 Davidson GP, Gall DG, Petric M, Butler DG, Hamilton JR. Human rotavirus enteritis induced in conventional piglets. f Clin Invest 1977; 60: 1402-9.

5 Molla MA, Rahman M, Sarker SA, Sack DA, Molla A. Stool electrolyte content and purging rates in diarrhea caused by rotavirus enterotoxigenic $\mathrm{E}$ coli, and $\mathrm{V}$ cholerae in children. $\mathcal{F}$ Pediatr 1981; 96: 835-8.

6 Booth IW. Nutritional management of acute diarrhoea. Clinical nutrition of the young child. Col 2. New York: Nestle Ltd, Vevey/Raven Press, 1994: 434-47.

7 Bueno J, Torres M, Almendros A, Carmona R, Nunez MC, Rios A, et al. Effect of dietary nucleotides on small intestiRios A, et al. Effect or dietary nucleotides on small intestinal repair after diarrhoea. Histologi

8 Bruckstein AH. Acute diarrhea. Am Fam Physician 1988; 38: 217-28.

9 Brown KH, Gastanaduy AS, Saavedra JM, Lembcke J, Rivas D, Robertson AD, et al. Effect of continued feeding on clinical and nutritional outcomes of acute diarrhea in children. $\mathcal{F}$ Pediatr 1988; 112: 191-200.

10 Rennie MJ. Lean tissue wasting in critically ill patients - is it preventable? British fournal of Intensive Care 1993; 3: 139-47.

11 Waterlow JC, Garlick PJ, Millward DJ. Protein turnover in mammalian tissues and in the whole-body. Amsterdam: North Holland, 1978.

12 Garlick PJ, McNurlan MA, Essen P, Wernerman J. Measurement of tissue protein synthesis rates in vivo: a critical analysis of contrasting methods. Am $\mathcal{f}$ Physiol 1994; 266: E287-97.

13 Rennie MJ, Smith K, Watt PW. Measurement of human tissue protein synthesis: an optimal approach. $\mathrm{Am} \mathcal{f}$ Physiol 1994; 266: E298-304.

14 Nunez MC, Ayudarte MV, Morales D, Suarez MD, Gil A. Effects of nucleotides on intestinal repair in rats with experimental chronic diarrhea. Fournal of Parenteral and Enteral Nutrition 1990; 14: 598-604.

15 Goda T, Yamada K, Bustamante S. Precocious increase of sucrase activity by carbohydrates in the small intestine of sucrase activity by carbohydrates in the smafl intestine of induced diarrhoea. 7 Pediatr Gastroenterol Nutr 1985; 4: induced 75 .

16 Holtug $\mathrm{K}$, Clausen MR, Hove $\mathrm{H}$, Christiansen J, Mortensen PB. The colon in carbohydrate malabsorption: short chain fatty acids, $\mathrm{pH}$, and osmotic diarrhoea. Scand f Gastroenterol 1992; 27: 545-52.

17 Garlick PJ, McNurlan MA, Preedy VR. A rapid and convenient technique for measuring the rate of protein synthesis in tissues by injection of $\left[{ }^{3} \mathrm{H}\right]$ phenylalanine. Biochem f 1980; 192: 719-23.

18 Gornall HG, Bardawill CJ, David MM. Determination of serum proteins by means of the biuret reaction. $7 \mathrm{Biol}$ Chem 1949; 177: 751-66.

19 Ashford AJ, Pain VM. Effect of diabetes on the rates of synthesis and degradation of ribosomes in rat muscle and thesis and degradation of ribosomes in rat $\mathrm{m}$
liver in vivo. $\mathcal{F}$ Biol Chem 1986; 261: 4059-65.

20 Munro HN, Fleck A. In: Munro HN, ed. Analysis of tissues and body fluids for nitrogenous constituents. Mammalian and body fluids for nitrogenous constituents. Mammalian protein metabolis

21 Downs TR, Wilfinger WW. Fluorometric quantification of DNA in cells and tissue. Anal Biochem 1983; 131: 538-47. 22 Preedy VR, Siddiq T, Why HJF, Richardson PJ. Ethanol 
toxicity and cardiac protein synthesis in vivo. Am Heart $\mathcal{F}$ 1994; 127: 1432-9.

23 Padykula HA, Herman E. Factors affecting the activity of adenosine triphosphate and other phosphatases as measured by histochemical techniques. $\mathcal{f}$ Histochem Cytochem 1955; 3: 161-9.

24 Padykula HA, Herman E. The specificity of the histochemical method for adenosine triphosphatase. f Histochem Cytochem 1955; 3: 170-95.

25 Hayashi M, Freiman DG. An improved method of fixation for formalin-sensitive enzymes with special reference to myosin adenosine triphosphatase. $\mathcal{F}$ Histochem Cytochem 1966; 14: 577-81.

26 Graham DY, Sackman JW, Estes MK. Pathogenesis of rotavirus-induced diarrhea (Preliminary studies in rotavirus-induced diarrhea (Preliminary studies in
miniature swine piglet). Dig Dis Sci 1984; 29: 1028-35.
27 Preedy VR, Siddiq T, Cook E, Black B, Palmer TN, Peters TJ. Alcohol and protein turnover. In: Palmer TN, ed. Alcoholism: a molecular perspective. New York: Plenum Alcoholism: a molecular perspective. New York: Plenum

28 Wapnir RA, Litov RE, Zdanowicz MM, Lifshitz F. Improved water and sodium adsorption from oral rehydration solutions based on rice syrup in rat model of osmotic diarrhea. F Pediatr 1991; 118: S53-61.

29 Preedy VR, Marway JS, Peters TJ. Use of the LieberDeCarli Liquid feeding regime with specific reference to the effects of ethanol on rat skeletal muscle RNA. Alcohol Alcohol 1989; 24: 439-45.

30 Forget P, Sodoyez-Goffaux F, Zappitelli A. Permeability of the small intestine to $\left[{ }^{51} \mathrm{Cr}\right]$ EDTA in children with acute gastroenteritis or eczema. $\mathcal{f}$ Pediatr Gastroenterol Nutr 1985; 4: 393-6. 